\title{
ANALISIS KONSUMSI PANGAN BERBASIS PROTEIN HEWANI DI KABUPATEN LEBONG: PENDEKATAN MODEL AIDS (ALMOST IDEAL DEMAND SYSTEM)
}

\author{
Animal Protein Based Food Consumption Analysis In District Of \\ Lebong: AIDS approach
}

\author{
Melli Suryanty dan Reswita \\ Jurusan Sosial Ekonomi Pertanian Fakultas Pertanian Universitas Bengkulu \\ Email : melli.suryanty@gmail.com
}

\begin{abstract}
This paper analyze the food consumtion base-on animal protein in Lebong. The study estimated a demand model for food base-on animal protein by using Almost Ideal Demand System (AIDS) model. It also estimated demand elasticities for different food items by the models. The result show that the demand model for food-based on animal protein can be explained by AIDS models. The model is consistent with demand theory. The coefficient of determination show range from 12.59 percent to 29.36 percent. However, the homogenity test for restriction parameters have not been explained by the model. The estimated own-price elasticity of demand for Chicken, Goldfish and Egg indicated that if the price fell by 10\% then the demand for the items would increase by $2.72 \%, 6.82 \%$, and $9.05 \%$, respectively. It show that the items are inelastic and necessities goods. The income elasticity of demand for Chicken, Goldfish and Egg were 1.000, 0.999, and 1.000, respectively. It shows that all commodities are normal goods. The estimates of cross price elasticity indicate that substitution effects of price change were not quite strong.
\end{abstract}

Key word: food consumtion, animal protein, AIDS model.

\section{PENDAHULUAN}

Protein merupakan salah satu zat gizi yang paling penting peranannya dalam pembangunan sumberdaya manusia. Bersama-sama dengan energi, kecukupan protein dapat digunakan sebagai indikator untuk melihat kondisi gizi masyarakat dan juga keberhasilan pemerintah dalam pembangunan pangan, pertanian, kesehatan dan sosial ekonomi secara terintegrasi. Protein dapat diperoleh dari bahan pangan nabati maupun hewani, namun dibandingkan dengan protein nabati, protein hewani mempunyai beberapa keunggulan. Salah satu yang terpenting adalah pembawa sifat keturunan dari 
generasi ke generasi dan berperan pula dalam proses perkembangan kecerdasan manusia.

Data Survei Sosial Ekonomi Nasional (Susenas) menunjukkan bahwa salah satu permasalahan penting konsumsi pangan di Indonesia adalah masih sangat rendahnya kontribusi pangan sumber protein hewani dalam menu makanan sehari-hari, serta ketergantungan yang tinggi terhadap pangan sumber protein nabati, khususnya serealia (beras). Rendahnya konsumsi pangan sumber protein hewani tersebut terkait erat dengan harga pangan sumber protein hewani yang relatif mahal dibandingkan dengan pangan sumber protein nabati. Di sisi lain, ketersediaan sumber pangan hewani di pasaran juga berpengaruh terhadap naik turunnya harga komoditi pangan hewani.

Dari berbagai komoditi pangan hewani yang terdapat di pasaran, komoditi Daging Ayam Ras, Ikan Mas dan Telur Ayam Ras merupakan tiga komoditi yang cukup familier dikonsumsi masyarakat sebagai sumber pangan hewani keluarga. Layak diduga bahwa ketiga komoditi tersebut memiliki fungsi subsitusi dan saling mempengaruhi satu sama lain. Untuk membuktikan dugaan tersebut, secara matematis ekonomi diperlukan suatu model fungsi permintaan yang mampu menjelaskan keterkaitan antar komoditas dalam suatu sistem yang saling terintegrasi. Model Almost Ideal Demand System (AIDS) memiliki keunggulan yakni menghasilkan persamaan simultan yang mampu menjelaskan keterkaitan antar komoditi (Desti et al, 2012), sehingga hubungan dua arah antar komoditas dapat dianalisa dengan baik. Model AIDS juga mampu mengestimasi respon permintaan pasar atas perubahan harga suatu komoditi (Jiumpanyarach, 2011), mengestimasi fungsi permintaan (Soedjana et al, 1994; Rahmawati \& Moeis, 2007), dan menghitung nilai elastisitas suatu komoditi (Tash et al, 2012).

Sebagai salah kabupaten hasil pemekaran wilayah, Kabupaten Lebong memiliki potensi menjadi sentra komoditi pangan di Propinsi Bengkulu, khususnya pangan berbasis protein hewani. Ketersediaan sumber pangan hewani di Kabupaten Lebong terlihat dari perkembangan produksi beberapa komoditi perikanan dan peternakan setempat. Selama kurun waktu tahun 20102011, produksi Ikan Mas mengalami peningkatan 19\% dengan total produksi sebesar 2249,8 ton dan peningkatan luas lahan mencapai 77 hektar (Irmanita, 2013). Berdasarkan data Dinas Perikanan dan Peternakan Kabupaten Lebong, diketahui data populasi ternak di Kabupaten Lebong pada tahun 2012 mencapai 131.963 ekor dengan 45,77\% diantaranya merupakan ayam pedaging, 0,64\% adalah sapi dan kerbau dan $0,61 \%$ adalah ayam petelur.

Merujuk pada potensi yang dimiliki Kabupaten Lebong tersebut, maka informasi mengenai pola konsumsi masyarakat atas komoditi pangan hewani sangat diperlukan. Informasi tersebut berguna untuk mengestimasi permintaan masyarakat atas komoditi-komoditi pangan hewani, seperti Ikan Mas, Daging Ayam Ras dan Telur Ayam Ras. Salah satu upaya yang dapat dilakukan adalah 
dengan mengestimasi model sistem permintaan beberapa komoditi pangan hewani. Oleh karena itu, tujuan dari penelitian ini adalah untuk: (a) mengestimasi model sistem permintaan beberapa komoditas pangan berbasis protein hewani dalam bentuk penerapan model persamaan simultan di Kabupaten Lebong; dan (b) menghitung nilai elastisitas permintaan beberapa komoditas pangan berbasis protein hewani di Kabupaten Lebong.

\section{METODE PENELITIAN}

\section{Data Dan Sumber Data Penelitian}

Data yang digunakan dalam penelitian ini adalah data sekunder, yaitu data Survei Sosial Ekonomi (SUSENAS) tahun 2012 yang dilakukan oleh Badan Pusat Statistik (BPS). Data yang dianalisis adalah data untuk Kabupaten Lebong yang mencakup data konsumsi pangan hewani rumah tangga. Pangan sumber protein hewani yang dianalisis meliputi komoditi ikan mas, daging ayam dan telur ayam. Selanjutnya, untuk pengolahan data digunakan nilai pengeluaran konsumsi ikan mas, nilai pengeluaran konsumsi daging ayam, nilai pengeluaran konsumsi telur ayam, harga rata-rata ikan mas, harga rata-rata daging ayam, harga rata-rata telur mas dari setiap rumah tangga yang dipilih. Berdasarkan data SUSENAS 2012, terdapat 463 rumah tangga yang menjadi responden survei di Kabupaten Lebong. Untuk menghindari nilai nol yang dapat mengganggu perhitungan model log seperti yang digunakan dalam penelitian ini, maka peneliti melakukan filterisasi (penyaringan) terhadap data survei yang diperoleh.

Dari populasi data tersebut, peneliti melakukan dua kali proses penyaringan data. Penyaringan data pertama dilakukan terhadap rumah tangga yang tidak mengkonsumsi satupun komoditi pangan hewani yang menjadi objek penelitian ini. Dari proses penyaringan pertama ini diperoleh sebanyak 351 rumah tangga. Selanjutnya dilakukan penyaringan kedua dengan mengeliminasi rumah tangga yang hanya mengkonsumsi satu atau dua komoditi pangan hewani yang menjadi objek penelitian. Dari hasil penyaringan ini diperoleh sebanyak 54 rumah tangga.

\section{Metode Analisis Data}

Metode analisis yang digunakan adalah analisis deskriptif dan analisis ekonometrika. Analisis deskriptif digunakan untuk melihat pola pengeluaran pangan sumber protein hewani, sedangkan analisis ekonometrika digunakan untuk menjelaskan respon permintaan pangan terhadap perubahan harga sendiri, harga komoditas lain, dan pengeluaran/pendapatan. 


\section{Model Analisis}

Model yang digunakan adalah model AIDS (Deaton dan Muelbaueur,1980) dalam bentuk aproksimasi linier (LA/AIDS) dengan formulasi sebagai berikut:

$$
W_{i}=\alpha_{i}+\sum_{j} \gamma_{i j} \log P_{j}+\beta_{i} \log \left(\frac{X}{P^{*}}\right)
$$

dimana i,j adalah 1. 2. 3 masing-masing menunjukkan kelompok atau grup komoditi ikan Mas, telur dan daging ayam, $\mathrm{W}_{\mathrm{i}}$ adalah pangsa dari kelompok pangan sumber protein ke-i terhadap total pengeluaran pangan sumber protein hewani $\left(w_{\mathrm{i}}\right.$ adalah $\left.\mathrm{p}_{\mathrm{i}} \mathrm{q}_{\mathrm{i}} / \mathrm{x}\right), \alpha, \beta, \gamma$ adalah parameter regresi untuk intersep, pengeluaran, harga agregat, $P_{j}$ adalah harga terbobot kelompok pangan sumber protein hewani ke-j $\left(\mathrm{P}_{\mathrm{j}}\right.$ adalah $\left.\sum W_{k} P_{k}\right), \mathrm{X}$ adalah pengeluaran total kelompok pangan sumber protein hewani, $\mathrm{P}^{*}$ adalah indeks harga stone, dimana $\log \mathrm{P}^{*}$ adalah $\sum W_{i} \log P_{i}$

Persamaan di atas konsisten dengan teori permintaan, jika memenuhi restriksi - restriksi sebagai berikut: (a) Restriksi adding up : $\sum \alpha_{i}=1, \sum \gamma_{i j}=$ $0, \sum \beta_{i}=0$, (b) Restriksi homogenity : $\sum \gamma_{i j}=0$, dan (c) Restriksi simetri : $\gamma_{\mathrm{ij}}=\gamma_{\mathrm{ji}}$

Melalui sifat agregasi/adding up berarti bahwa penjumlahan dari permintaan merupakan pengeluaran. Sifat homogenitas berarti permintaan adalah homogeny berderajat nol dalam harga dan pengeluaran. Sedangkan sifat simetri berarti pula penurunan harga silang dari permintaan adalah simetri. Pada persamaan model AIDS ini dapat dicari elastisitas permintaan. Elastisitas permintaan dapat diturunkan sebagai barikut: (a) Elastisitas harga barang: $\varepsilon_{\mathrm{ii}}=$ $\left(\gamma_{i i}-\beta_{i} W_{i} / W_{i}\right)-1,(b)$ Elastisitas silang $: \varepsilon_{i j}=\left(\gamma_{i j}-\beta_{i} W_{j}\right) / W_{i}(i \neq j)$, dan $(c)$ Elastisitas pendapatan $: \eta_{\mathrm{i}}=1+\beta_{\mathrm{i}} / \mathrm{W}_{\mathrm{i}}$.

Untuk memudahkan penganalisaan dari data yang diperoleh digunakan program pengolahan data yang menggunakan sistem komputerisasi, yaitu dengan menggunakan program shazam (White, 1993)

\section{HASIL DAN PEMBAHASAN}

\section{Hasil Estimasi Model Almost Ideal Demand System}

Hasil estimasi model AIDS tanpa restriksi disajikan pada Tabel 1. Hasil estimasi tanpa restriksi merupakan estimasi yang dilakukan tanpa memperhatikan beberapa sifat yang harus dipenuhi oleh fungsi permintaan, yaitu restriksi adding up, restriksi simetry dan restriksi homogenitas.

Nilai koefisien determinasi $\left(\mathrm{R}^{2}\right)$ untuk masing-masing persamaan permintaan dari komoditi pangan berbasis protein hewani tanpa restriksi berkisar antara 12,59 persen hingga 29,36 persen. Nilai tersebut menunjukkan bahwa kemampuan model dalam menerangkan keadaan sebenarnya. Hasil pengujian thitung dari sistem permintaan tiga komoditi pangan berbasis protein hewani tanpa

104 | Melly Suryanti dan Reswita, Analisa Konsumsi Pangan berbasis Protein. 
restriksi yang disajikan pada tabel 1 menunjukkan banyak koefisien pendugaan yang nyata pada taraf kepercayaan 90 hingga 99,9 persen berjumlah 7 dari 15 buah koefisien pendugaan. Sedangkan untuk mengetahui kesesuaian suatu model dapat diketahui dengan melakukan uji-F. Dari tabel tersebut terlihat bahwa sistem permintaan pangan dari masing-masing komoditi berbasis protein hewani tanpa restriksi mempunyai tingkat keberartian pada tingkat nyata 10 persen.

Tabel 1. Koefisien Pendugaan Sistem Permintaan Pangan Berbasis Protein Hewani Tanpa Restriksi di Kabupaten Lebong

\begin{tabular}{|c|c|c|c|c|c|c|}
\hline \multirow{2}{*}{$\begin{array}{l}\text { Sumber } \\
\text { protein }\end{array}$} & \multicolumn{5}{|c|}{ Koefisien Pendugaan } & \multirow{2}{*}{$\mathrm{R}^{2}$} \\
\hline & ai & үi1 & үi2 & yi3 & $\beta \mathrm{i}$ & \\
\hline $\begin{array}{l}\text { Daging } \\
\text { Ayam }\end{array}$ & $\begin{array}{l}-1.4350^{* *} \\
(0.71014)\end{array}$ & $\begin{array}{r}0.29998^{* * * *} \\
(0.066719)\end{array}$ & $\begin{array}{r}-0.055341 \\
(0.047487)\end{array}$ & $\begin{array}{l}-0.071005^{*} \\
(0.035614)\end{array}$ & $\begin{array}{r}0.00000049347 \\
(0.00000092176)\end{array}$ & 29.36 \\
\hline Ikan Mas & $\begin{array}{l}0.087787 \\
(0.81124)\end{array}$ & $\begin{array}{c}-0.13710^{*} \\
(0.076201)\end{array}$ & $\begin{array}{r}0.12176^{*} \\
(0.054456)\end{array}$ & $\begin{array}{r}0.051695 \\
(0.040831)\end{array}$ & $\begin{array}{r}-0.00000065533 \\
(0.00000078172)\end{array}$ & 12.59 \\
\hline $\begin{array}{l}\text { Telur } \\
\text { Ayam } \\
\text { Ras }\end{array}$ & $\begin{array}{l}2.3505^{\star * *} \\
(0.67445)\end{array}$ & $\begin{array}{l}-0.16245^{* *} \\
(0.063264)\end{array}$ & $\begin{array}{r}-0.067218 \\
(0.045377)\end{array}$ & $\begin{array}{r}0.019319 \\
(0.034038)\end{array}$ & $\begin{array}{r}0.00000018394 \\
(0.00000045300)\end{array}$ & 18.62 \\
\hline
\end{tabular}

Sumber: Data Olahan

Keterangan: * $, * * * * *, * * * *$ secara berturutt turut signifikan pada taraf $10 \%, 5 \%, 1 \%$, dan $0.1 \%$

Untuk mengetahui apakah restriksi dapat diterapkan pada model yang digunakan, sebelumnya dilakukan pengujian restriksi terhadap model. Pengujian restriksi terhadap model meliputi restriksi adding up, restriksi homogenitas, restriksi simetri dan kombinasi antara ketiga restriksi. Tujuan dilakukan pengenaan restriksi adalah agar sesuai dengan teori permintaan. Berikut merupakan hasil pengujian restriksi terhadap model:

Tabel 2. Hasil Pengujian Restriksi Homogenitas, Adding Up, dan Symetri

\begin{tabular}{lccc}
\hline \multirow{2}{*}{ Restriksi } & \multicolumn{2}{c}{ Chi Square } & \multirow{2}{*}{ Keterangan } \\
\cline { 2 - 3 } & Hitung & Probabilitas & \\
\hline Homogenitas & 1,003927 & 0,8003 & Terima $\mathrm{H}_{0}$ \\
Adding Up & 9,568388 & $0,08843^{* *}$ & Tolak $\mathrm{H}_{0}$ \\
Symetri & 16,664732 & $0,00024^{* * *}$ & Tolak $\mathrm{H}_{0}$ \\
\hline
\end{tabular}

Sumber: Data Olahan

Keterangan:**, *** secara berturut - turut signifikan pada taraf kepercayaan $(\alpha)=0.1$, dan 0.01 
Tabel 2 menunjukkan bahwa restriksi yang dapat digunakan atau berlaku pada model adalah restriksi adding up dan simetri. Restriksi homogenitas tidak dapat digunakan pada model. Hal ini berarti sifat homogenitas yang menyatakan bahwa total parameter regresi untuk harga agregat dari setiap jenis komoditi tidak dapat diterapkan. Tidak dapat digunakannya sifat homogenitas ini menyebabkan hasil yang diperoleh tidak dapat dijadikan perbandingan dengan hasil penelitian lainnya. Dengan hasil pengujian retriksi di atas, maka retriksi yang digunakan untuk pembahasan lebih lanjut adalah mengikuti kaidah kombinasi teriksi adding up dan simetri.

Untuk pendugaan elastisitas permintaan komoditi pangan rumah tangga berbasis protein hewani di Kabupaten Lebong digunakan hasil pendugaan tanpa retriksi dan dengan retriksi. Hal ini bertujuan untuk melihat berpengaruh tidaknya pengenaan retriksi terhadap model. Pendugaan elastisitas dengan retriksi merupakan hal yang sangat penting karena dapat diperolehnya sifatsifat fungsi permintaan yang diperoleh dari teori.

Penggunaan elastisitas pengeluaran di sini lebih dikarenakan tingkat kepercayaan data dibandingkan dengan pendapatan. Adapun elastisitas yang akan diduga yaitu elastisitas harga sendiri, elastisitas harga silang dan elastisitas pengeluaran dari masing-masing komoditi pangan berbasis protein hewani dengan kondisi tanpa retriksi dan dengan retriksi.

Tabel 3. Koefisien Pendugaan Sistem Permintaan Pangan Berbasis Protein Hewani Dengan Restriksi di Kabupaten Lebong

\begin{tabular}{|c|c|c|c|c|c|c|}
\hline \multirow{2}{*}{$\begin{array}{l}\text { Sumber } \\
\text { Protein } \\
\text { Hewani }\end{array}$} & \multicolumn{5}{|c|}{ Koefisien Penduga } & \multirow{2}{*}{$\mathrm{R}^{2}$} \\
\hline & ai & үi1 & үi2 & yi3 & $\beta \mathrm{i}$ & \\
\hline \multirow{2}{*}{$\begin{array}{l}\text { Daging } \\
\text { Ayam }\end{array}$} & 0.49800 & 0.0052508 & 0.0054106 & -0.010661 & -0.0000060315 & \multirow{2}{*}{-19.18} \\
\hline & $(0.0014811)$ & $(0.019964)$ & (0.019037) & $(0.038460)$ & (0.0000018577) & \\
\hline \multirow{2}{*}{ Ikan Mas } & 0.33795 & -0.053906 & 0.058370 & -0.0044645 & 0.0000040775 & \multirow{2}{*}{-1.47} \\
\hline & $(0.034568)$ & $(0.053709)$ & $(0.044741)$ & $(0.039648)$ & $(0.0000027989)$ & \\
\hline \multirow{2}{*}{$\begin{array}{l}\text { Telur } \\
\text { Ayam } \\
\text { Ras }\end{array}$} & 0.16005 & 0.048655 & -0.63621 & 0.014966 & 0.0000019540 & \multirow[t]{2}{*}{-5.47} \\
\hline & $(0.034549)$ & $(0.053413)$ & $(0.044193)$ & $(0.037567)$ & $(0.0000026450)$ & \\
\hline
\end{tabular}

Sumber: Data Olahan

Berdasarkan hasil pada tabel 2 dan tabel 3 dapat dilihat dengan jelas perbedaan tanpa retriksi dan dengan retriksi terhadap koefisien penduga sistem permintaan komoditi pangan berbasis protein hewani di Kabupaten Lebong. Nilai R-Square yang diperoleh dengan menggunakan retriksi menunjukkan persentase nilai yang negatif. Oleh karena itu, model permintaan yang akan 
dianalisis nilai elastisitasnya pada tahap selanjutnya adalah model yang tidak menggunakan retriksi.

\section{Elastisitas Harga Permintaan}

Nilai elastisitas harga sendiri untuk ketiga komoditi pangan berbasis protein hewani disajikan pada tabel 4. Berdasarkan hasil perhitungan, nilai elastisitas harga ketiga komoditi objek penelitian bertanda negatif.

Tabel 4. Elastisitas harga untuk permintaan sistem pangan berbasis protein hewani di Kabupaten Lebong

\begin{tabular}{lcc}
\hline \multicolumn{1}{c}{ Komoditi } & $\begin{array}{c}\text { Nilai Elastisitas } \\
\text { Harga Permintaan }\end{array}$ & Sifat Elastisitas \\
\hline Daging Ayam Ras & -0.271504553 & Inelastis \\
Ikan Mas & -0.68247221 & Inelastis \\
Telur Ayam Ras & -0.905649274 & Inelastis \\
\hline
\end{tabular}

Sumber: Data Olahan

Nilai elastisitas harga permintaan menunjukkan dampak perubahan harga komoditi yang bersangkutan terhadap tingkat konsumsi komoditi tersebut. Nilai elastisitas permintaan harga sendiri untuk ketiga komoditi memiliki tanda negatif. Tanda negatif pada nilai elastisitas harga permintaan sudah sesuai dengan teori permintaan. Dimana hal ini berarti apabila harga meningkat maka jumlah konsumsi terhadap ketiga komoditi tersebut akan menurun yang mengakibatkan pangsa pengeluaran untuk komoditi tersebut ikut turun.

Dari hasil penelitian ini didapat jika terjadi kenaikan harga Daging Ayam Ras sebesar 10 persen, akan terjadi penurunan pada jumlah konsumsi sebesar 2,72 persen. Jika terjadi kenaikan harga Ikan Mas sebesar 10 persen, akan terjadi penurunan jumlah konsumsi sebesar 6,82 persen. Dan jika harga telur mengalami kenaikan sebesar 10 persen, maka jumlah telur yang dikonsumsi akan turun sebesar 9.05 persen.

Secara agregat di Kabupaten Lebong, seluruh komoditi yang diteliti bersifat inelastis. Oleh karena itu, dapat diinterpretasikan bahwa Daging Ayam Ras, Ikan Mas dan Telur Ayam Ras merupakan barang kebutuhan (necessities). Respon perubahan jumlah yang diminta untuk komoditi-komoditi tersebut, persentasenya lebih kecil dibanding persentase perubahan harga.

\section{Elastisitas Pendapatan}

Nilai elastisitas pendapatan dari masing-masing komoditi yang diteliti dapat dilihat pada tabel 5. Tabel ini memperlihatkan bahwa nilai elastisitas pendapatan untuk seluruh komoditi bertanda positif. Adanya peningkatan pengeluaran rumah tangga dipengaruhi peningkatan permintaan suatu barang. Keadaan ini menunjukkan bahwa semua komoditi yang diteliti termasuk dalam kelompok barang normal. 
Tabel 5. Elastisitas pendapatan untuk permintaan sistem pangan berbasis protein hewani di Kabupaten Lebong

\begin{tabular}{lcc}
\hline \multicolumn{1}{c}{ Komoditi } & Nilai Elastisitas & Sifat Elastisitas \\
\hline Daging Ayam Ras & 1.000001198 & Elastis \\
Ikan Mas & 0.999998291 & Inelastis \\
Telur Ayam Ras & 1.000000898 & Elastis \\
\hline
\end{tabular}

Sumber: Data Olahan

Elastisitas pendapatan dapat menggambarkan suatu komoditi tertentu apakah termasuk ke dalam kelompok pangan yang merupakan kebutuhan pokok ataukah kolompok superior/mewah. Suatu komoditi dikatakan menjadi kebutuhan pokok apabila nilai elastisitas pengeluarannya kurang dari 1 dan mewah apabila lebih dari 1 (Sudarso dalam Pakpahan, 2012).

Tabel 5 menunjukkan bahwa komoditi Ikan Mas termasuk dalam kelompok kebutuhan pokok, sedangkan Daging Ayam Ras dan Telur Ayam Ras tergolong dalam kelompok superior/mewah. Teori ekonomi menyatakan bahwa jika suatu barang pokok tertentu dibutuhkan dalam jumlah yang besar maka barang tersebut akan tidak elastis dibanding barang bukan kebutuhan pokok. Kecilnya nilai elastisitas pendapatan untuk komoditi Ikan Mas menandakan bahwa konsumsi ikan sudah mencukupi kebutuhan rumah tangga bagi masyarakat Lebong, sehingga perubahan pendapatan hanya menyebabkan pertambahan permintaan komoditas Ikan Mas yang cukup sedikit dan rumah tangga akan mengalihkan pengeluarannya untuk komoditi lain yang konsumsinya lebih rendah.

\section{Elastisitas Silang}

Elastisitas silang adalah koefisien yang menunjukkan besarnya perubahan permintaan terhadap suatu barang apabila terjadi perubahan harga terhadap barang lain. Nilai elastisitas silang bertanda positif menunjukkan bahwa komoditi tersebut merupakan subsitusi dari komoditi lain, sedangkan tanda negatif menunjukkan bahwa komoditi tersebut bersifat komplementer terhadap komoditi yang lain (Sukirno, 2005). Nilai elastisitas silang untuk masing-masing komoditi pangan hewani terhadap komiditi pangan hewani lainnya pada penelitian ini ditampilkan pada Tabel 6.

Dari Tabel 6 tersebut diketahui bahwa seluruh nilai elastisitas harga silang untuk setiap komoditi bertanda positif. Ini dapat diinterpretasikan bahwa komoditi Daging Ayam Ras, Ikan Mas dan Telur Ayam Ras memiliki hubungan substitusi antara satu sama lain. Hubungan subsitusi diantara ketiga komoditi yang diteliti umumnya relatif lemah (kurang begitu kuat). Nilai elastisitas harga silang antar dua komoditi yang kurang dari satu akan bersifat inelastis. Dan nilai elastisitas harga silang dengan nilai mutlak kurang dari 0,5 menunjukkan hubungan subsitusi yang terbentuk relatif rendah. 
ISSN: $1412-8837$

Tabel 6. Elastisitas silang untuk permintaan sistem pangan berbasis protein hewani di Kabupaten Lebong

\begin{tabular}{lccc}
\hline \multirow{2}{*}{ Komoditi } & \multicolumn{3}{c}{ Elastisitas Harga Silang } \\
\cline { 2 - 4 } & Daging Ayam Ras & Ikan Mas & Telur Ayam Ras \\
\hline Daging Ayam Ras & - & 0.782293 (inelastis) & 1.465051537 (elastis) \\
Ikan Mas & 0.2956917 (inelastis) & - & 0.594655227 (inelastis) \\
Telur Ayam Ras & 0.0469158 (inelastis) & 0.05038 (inelastis) & - \\
\hline
\end{tabular}

Sumber: Data Olahan

Temuan menarik tampak pada subsitusi antara Telur Ayam Ras dan Daging Ayam Ras. Hubungan yang terbentuk bersifat subsitusi dan elastis. Ini berarti, apabila terjadi kenaikan harga Telur Ayam Ras sebesar 10 persen maka konsumsi terhadap Daging Ayam Ras akan meningkat sebesar 14,65 persen.

\section{SIMPULAN DAN SARAN}

\section{Simpulan}

Adapun kesimpulan yang dapat ditarik dari penelitian ini antara lain:

1. Model sistem permintaan pangan berbasis protein hewani yang dijelaskan dengan model AIDS konsisten dengan teori permintaan. Nilai koefisien determinasi yang dihasilkan antara 12,59 persen hingga 29,36 persen. Pengujian terhadap parameter retriksi homogenitas tidak berhasil dipenuhi oleh model, hal berbeda untuk retriksi adding up dan retriksi symetri.

2. Nilai elastisitas harga untuk komoditi Daging Ayam Ras, Ikan Mas dan Telur Ayam Ras secar berturut - turut adalah -0,272, -0,682 dan -0,905. Artinya, seluruh komoditi yang diteliti bersifat inelastis dan merupakan barang kebutuhan (necessities).

3. Nilai elastisitas pendapatan untuk komoditi Daging Ayam Ras, Ikan Mas dan Telur Ayam Ras secar berturut - turut adalah1,000, 0,999 dan 1,000. Nilai elastisitas pendapatan untuk seluruh komoditi bertanda positif. Keadaan ini menunjukkan bahwa semua komoditi yang diteliti termasuk dalam kelompok barang normal.

4. Nilai elastisitas silang untuk setiap komoditi yang diteliti bertanda positif. Ini dapat diinterpretasikan bahwa komoditi Daging Ayam Ras, Ikan Mas dan Telur Ayam Ras memiliki hubungan substitusi antara satu sama lain.

\section{Saran}

1. Perlu dilakukan penelitian lanjutan dengan memperluas lingkup komoditi yang diteliti. Untuk menghindari nilai nol dalam perhitungan proporsi pengeluaran, maka sebaiknya digunakan pengelompokan komoditas. 
2. Perlu dilakukan modifikasi terhadap model dengan menambahkan variabel sosial dan demografi, seperti status miskin, tingkat pendidikan kepala keluarga/istri, ukuran rumah tangga, lokasi rumah tangga (kota atau desa), dan lain-lain. Penambahan variabel tersebut diharapkan kajian pola konsumsi rumah tangga dapat dianalisis dari banyak sudut pandang.

\section{DAFTAR PUSTAKA}

Deaton, M. and J. Muelbauer. 1980. An Almost Ideal Demand System. American Economic Review. 70(3): 312-326

Desti, Cesa Febri, Dodi Devianto, Izzati Rahmi HC. Analisis Keterkaitan Antar Komoditas Protein Dengan Menggunakan Model AIDS. Jurnal Matematika UNAND. 2(3): 162 - 166.

Irmanita, Fenny. 2013. Pengembangan Budidaya Ikan Air Tawar Di Kabupaten Lebong. $\quad$ http://agribisnispeternakan.wordpress.com/2013/05/13/ pengembangan-budidaya-ikan-air-tawar-di-kabupaten-lebong/\#more-

78). Diakses tanggal 25 Mei 2014

Jiumpanyarach, Waripas. 2011. Estimation of Demand System in An AIDS Model: The Opportunity for Exporting Thai Agricultural Products. European Journal of Business and Economic, 5: ISSN 1804-5839.

Pakpahan, Franda. 2012. Analisis Konsumsi Pangan Rumah Tangga Di Desa Talang Boseng Kecamatan Pondok Kelapa Kabupaten Bengkulu Tengah. Skripsi. Fakultas Pertanian. Universitas Bengkulu.

Rahmawati dan Moeis. 2005. Estimasi Fungsi Permintaan Makanan Dalam Analisia

Diversifikasi Pangan Untuk Menurunkan Permintaan Beras Propinsi Jawa Barat. (http://www.scribd.com/doc/28438869/Estimasi-Fungsi-anMakanan-Dalam-Analisa-Diversifikasi-Pangan-Untuk-Menurunkan-anBeras-Propinsi-Jawa-Barat-2005). Diakses tanggal 25 Mei 2014

Soedjana, Tjeppy D; Tahlim Sudaryanto dan Rosmiati Sayuti. 1994. Estimasi Parameter Permintaan Beberapa Komoditi Peternakan di Jawa. Jurnal Penelitian No.1, Maret 1994. Pusat Penelitian dan Pengembangan Peternakan. Bogor.

Sukirno, Sadono. 2005. Teori Pengantar : Mikro Ekonomi. Edisi Tiga. Rajawali Press.

Tash, M. Nabi Shahiki, Javad Shahraki and Samane Nouri Jangi. 2012. Estimating the AIDS Model for Rural Households in Iran. International Journal of Academic Research inBusiness and Social Science. Vol. 2 No.8 August 2012. ISSN: 2222-6990.

White, Kenneth J. 1993. A Computer Handbook Using Shazam. Mc Graw Hill Book Company. New York.

110 | Melly Suryanti dan Reswita, Analisa Konsumsi Pangan berbasis Protein. 